\title{
Development of Android-Based Elin Game As Learning Media for Industrial Electronics
}

\section{Mochammad Sukardjo and Vina Oktaviani}

Vocational Electronics Engineering Education Studies Program, Electrical Engineering, Faculty of Engineering, State University of Jakarta, Rawamangun, Indonesia

\section{Abstract}

Lab Learning on Electronics Industry is a must course. This is necessary for students so they have good skills. Lab Learning need practice equipment that enough to fit the quantities of students. But in fact the quantities of material and practice equipment are not being sufficient. In addition, there is no learning media that can support the courses. This study aims to develop lab learning media with technology based on game with android-base that can help the students to understand the lab course everywhere, all the time. This study using Research and Development Method (RnD) with Model of Multimedia Development Life Cycle (MDLC). This study is done through

Corresponding Author: Vina Oktaviani

email: vinaoktaviani@unj.ac.id

Received: 11 January 2019 Accepted: 14 February 2019 Published: 25 March 2019

Publishing services provided by Knowledge E

(c) Mochammad Sukardjo and Vina Oktaviani. This article is distributed under the terms of the Creative Commons

Attribution License, which permits unrestricted use and redistribution provided that the original author and source are credited.

Selection and Peer-review under the responsibility of the $3 \mathrm{rd}$ ICTVET 2018 Conference Committee.

\section{G OPEN ACCESS} six stage that is: 1. Concept; 2) Design; 3) Collection of material; 4) Assembly; 5) Testing; and 6) Distribution. The evaluation process feasibility learning media done by granting the survey to Media Experts, Lecture experts, and respondents trial use. Based on the assessment field test by students for Industrial Electronics they can get $88.27 \%$ counted as very good. Android-Based Elin Game as Learning Media in Industrial Electronics is very reasonable and effective for teaching.

Keywords: Game, Android, Learning Media, Industrial Electronics, Multimedia Development Life Cycle (MDLC).

\section{Introduction}

Engineering Faculty is one of many Faculty in Jakarta State University which has some course of study, and one of those courses is Electronic Engineering Education. Based on the book BPA UNJ, Electronic Engineering Education main purpose is to prepare Graduated Students with high capability to become teacher in Vocational High School. In addition, the graduate student also can work on industry, Hence, to prepare the student to enter the world of work (both of as teacher or working in Industry) the quality of knowledge both Theory and Practical should be good, right and quality. One of indicator's quality for education is graduates who mostly produced having knowledge, skill and good manners. This quality can be seen with mostly student graduate in time and obtain index achievement good. In equip graduate knowledge and skill in the 
study Electronic Engineering Education there are some engineering lecture, and one of them is Industrial Electronics (ELIN). In order the students each have the skills in the psychomotor, good manners and morals they need materials and equipment or private practice the same amount as the students.

Digital Games are becoming a new form of interactive content and game playing provides an interactive and collaborative platform for learning purposes. Games provide a context where participants are continually challenged and confronted with increasingly difficult problems as they progress. The use of game as a medium learning can work for some device technology one of them is a smart phone. Application mobile Game Based Learning ( $\mathrm{mGBL}$ ) built in line with the rate education and also adjusted to the curriculum apply. Mobile game as a medium learning can be improved and be utilized in accordance with the learning design. Mobile game be able to support the creation of the new learning, effective, and pleasing to achieve goals learning.

Digital mobile game-based learning is the product of a balance between learning and gaming elements (Mehran, Fattaneh dan Saeed: 2018). In the other words, entertaining intrinsic of games has potentials to be coupled with the learning process and improve it. Therefore, two important elements of educational games are entertainment and educational component separating educational games from entertaining games and e-learning applications.

The development of game ELIN in mGBL is conducted in ordered and in accordance into each step.

The outcome of the investigations resulted in game ELIN in that way could be used as Lab Learning Media. This chapter will conclude that ELIN game can be used as Lab Learning Media for Electronic Engineering Education.

\section{Methods and Equipment}

\subsection{Equipment}

This research object is students of electronics engineering vocational and education in Faculty of Engineering State of Jakarta University. The students are those who take industrial electronics courses.

\subsection{Methods}




\subsubsection{Game development method}

Development Model as a reference development of ELIN game is using R\&D Method (Research \& Development) with model MDLC (Multimedia Development Life Cycle. The stage for this development is:

\section{Concept Stage}

At this stage do identification and estimate the needs resulting from observations on a research and do analyze about media technology

2. Design/Planning Stage

In the planning stages using three stage whose are used before make the notation game that is DFD (Data Flow Diagram) and Storyboard. Analyze Method that used to build this educational game application is procedural Model.

\section{Collect Data Stage}

At this stage, the matter related to teaching material/learning material obtained from interview to Lecturer of Industrial Electronics. Existing Matter refer to a curriculum that provided.

\section{Assembly}

The assembly (making) is the stage in which all material objects or multimedia made. Making an application based on Data Flow Diagram (DFD) and storyboard. All objects or material made and combined into one whole application.

5. Testing

This stage called equally testing stage alpha (alpha test) where testing done by the maker of the application or environment its own maker. Testing alpha including functional test, feasibility test by Lecture Expert and Media Expert. Next up betha testing. Testing betha including respondent test and T-Test.

\section{Distribution}

At this stage, applications that has been completed tested and was declare as a good purpose, will be distributed to VIIA Class students in SMPN 269 Jakarta. 


\subsubsection{Data collection method}

The technique of data collection is the main step in a study, because the main objective of the study is to get the data (Sugiyono, 2016: 137). The technique of collecting data which used in this research were:

1. Observation Method. Observation done to obtain data that support the study

2. Interview Method. In this method interview used to get information through lecturers about the curriculum and obstacle in learning.

3. Questionnaire Method. The survey given to media experts to know feasibility of media in learning process, and to lecturer expert to know feasibility of material. Data of student response during learning taken with questionnaire survey about the use of game ELIN in Industrial Electronic Lecture.

\subsubsection{Data analysis method}

In this research, there are 4 kind of data there are validation instrument by experts, validation matter by expert, validation media learning by experts, the survey/the questionnaire response by students.

1. An Analysis Data result of Validation Instruments

Validation instrument is done to know how much instrument can measuring the object to be observed. Validation instrument test is using Lawshe's CVR (Content Validity Ratio)

Method and CVI (Content Validity Index). Lawshe (1975) proposes that each of SME (Subject Matter Experts) to answer question for each item with three option named: (1) Essential, (2) Useful but not Essential, (3) Not Required. Lawshe validity according to the formula used to analyze or counting each item:

$$
C V R=(n \varepsilon-N / 2) /(N / 2)
$$

Note: $\mathrm{CVR}=$ Content Validity Ratio, $\mathrm{n} \varepsilon=$ quantities of Experts who answer Essensial, $\mathrm{N}=$ total of Experts.

After count CVR (Content Validity Ratio) the next step is to calculate CVI (Content Validity Index) from all of question. CVI (Content Validity Index) calculated based on the average of CVR (Content Validity Ratio). Formula to calculated CVI (Content Validity Index) is:

CVI = CVR / (Quantities of Questions or statements) 
Note: CVR = Content Validity Ratio Total

The result of $\mathrm{CVI}$ calculated has ratio from 0 to 1 which can categorize based on CVI value. CVI Value table can be seen as below:

TABLE 1: CVI Calculated Ratio.

\begin{tabular}{|l|c|c|}
\hline No. & Category & Ratio \\
\hline 1 & Not Suitable & $0-0,33$ \\
\hline 2 & Suitable & $0,34-0,67$ \\
\hline 3 & Very Suitable & $0,68-1$ \\
\hline
\end{tabular}

\section{An Analysis Data Result from Lecture Expert \& Media Expert}

The survey that used to test the feasibility by Media Expert and Material Expert are using Guttman scale with two options, 1 as YES and 0 as NO. Guttman Scale used because it requires firm answer is learning media eligible for use or no. The results of the survey on every aspect must have answer yes to be announced eligible for use, if there was a no answers these aspects must be resolved. The validation data instrument from two Experts will be analysis using Coefficient Contain formula by Gregory with the aspect judge by expert (Retnawati, 2016: 32). Before counting the validity of the instrument and the near future after receiving the data from the answers of the each of an instrument who were judged to be, the answers need to arranged beforehand with prepare contingency table to calculate the Gregory Index. Contingency Table to calculate the Gregory Index to be demonstrated at tables as below:

TABLE 2: Contingency Table to Calculate Gregory Index.

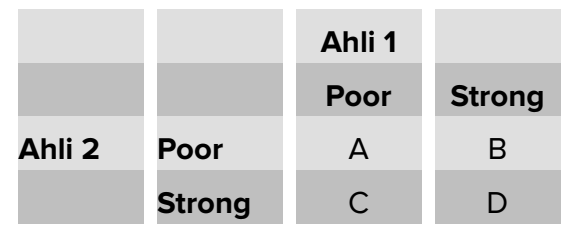

After get the data from experts, move the data into Contingency Table by compared the corpuscular list of two expert with relevancy category strong with all corpuscular list (to grouping the strong and the poor one). The score for each answer can be calculated with formula:

$$
\text { Coefficient of Content Validity }=\frac{D}{A+B+C+D}
$$

\section{Note:}

$\mathbf{A}=$ the answer of one expert NO and the other one NO as well (Poor-Poor) 
$\mathbf{B}=$ the answer of one expert YES and the other one NO (Strong-Poor)

$\mathbf{C}=$ the answer of one expert NO and the other one YES (Poor-Strong)

$\mathbf{D}=$ the answer of one expert YES and the other one YES as well (Strong-Strong)

The next step is the result of calculation that has coefficient of the validity interpreted it into the Agreement Expert index (Retnawati, 2016: 33). Table Agreement Expert Index can be show below:

TABLE 3: Table Agreement Expert Index.

\begin{tabular}{|l|l|c|}
\hline No & Percentage & Category \\
\hline 1 & $<0,4$ & Low Validity \\
\hline 2 & $0,4-0,8$ & Enough Validity \\
\hline 3 & $>0,8$ & High Validity \\
\hline
\end{tabular}

3. An Analysis from Questionnaire Survey to Respondents

The survey given to students as a respondent used Likert Formula which consist of five options (Akdon, 2012:21) as shown in the table:

TABLE 4: Criteria for Respondent Questionnaire using Likert Formula.

\begin{tabular}{ll} 
No. & Criteria \\
\hline 1 & SS/ Very Agree \\
2 & ST/ Agree \\
3 & CS/ Not so Agree \\
4 & TS/ Not Agree \\
\hline 5 & STS / Not Really Agree
\end{tabular}

\begin{tabular}{|c|c|}
\hline Score & \\
\hline Positive & Negative \\
\hline 5 & 1 \\
\hline 4 & 2 \\
\hline 3 & 3 \\
\hline 2 & 4 \\
\hline 1 & 5 \\
\hline
\end{tabular}

The data was obtained from respondents watchful such students analyzed in order to know how student's response about education media ELIN game that has been used, do education media ELIN game useful or not.

\section{Result}

\subsection{Concept stage}

In this stage need to set the purpose of the product, the purpose of the product will focus on the material which is compatible with basic competence that include in the exist curriculum. The ELIN game learning media can give the information to students about the material in lab learning on study Industrial Electronics. In this stage too will 
be done identification about student's characteristic who will use the Education game learning media. The user's characteristic is 1) The Students of Industrial Electronic Study.

\subsection{Planning stage}

In the collection data method will be used 3 steps before made the Notation Block games there are Context Data, Data Flow Diagram (DFD) and storyboard. Analysis Modelling approach that used to prepare the education game is procedural modelling. This software will used Data Flow Diagram (DFD).

1. Context Diagram. Context diagram is a diagram which draw input, process and output as global which happen in the on-software system whose will made. The context diagram of this ELIN Game can be seen in the picture

2. Data Flow Diagram (DFD). Data flow diagram (DFD) is a technique which draw the data and information which used as a travel data from input to output. DFD made if the contex diagram still need any more process that need more explanation. This Data Flow Diagram of this ELIN game can be seen in the picture.

3. Storyboard. In this stage we did planning the layout and prepare sketch design as a storyboard which show the product start from opening, main menu which show sub menu learning and play till the last level of the game till the end. The good layout will make an interesting game.

\subsection{Data collection stage}

In this stage we will prepare all the data we need, such a material, animation picture, audio and video. The material we need for this ELIN game is based on Curriculum of Industrial Electronics study.

\subsection{Assembly stage}

The assembly is stage where whole object multimedia built upon storyboard and structure navigation derived from the design. At this stage we used some software in manufacturing namely adobe illustrator, adobe photoshop cc14, mix craft pro studio 6 and adobe after effect cc14 for making illustration, audio and video, and programming. This stage is stages by which product ready to be operated consisting of explanation for the environment and the implementation of the program. The support application to 
be applied to the environment, so in this case must consider specifications hardware and software in making the ELIN game.

\subsection{Testing stage}

1. Media Implantation

In this stage, media that prepare by storyboard which has been planned in the design stage. ELIN Game Education as a learning media has some contents and display, there are: content, opening page, main page, playing page and exit from game.

\section{Product Feasibility}

The product that has been develop will be test the feasibility before implantation the media as a learning media to the students of Electronic Engineering Education. It has 2 tests to know the feasibility of the ELIN game as a learning media, which is Functional Test and Expert Test.

\section{Functional Test Result (Black Box)}

Base on the Black Box Test will get the result which function can running well and based on the command input.

\section{Expert Test Result}

The software which has prepared then will be doing the test by experts, Lecture Expert and Media Expert. Both of the test will be done to know if the media already feasibility or need more revision. Based on the feasibility test by both experts, will get expert validity coefficient value 1 , this result is a high validity. After get the conclusion as a feasibility game, the next step is ELIN Game will be test to students, and will get the percentage of feasibility product as whole $89 \%$, which conclude that ELIN game is "VERY SUITABLE" for Learning Media in Industrial Electronic Lab Study.

\section{Discussion}

ELIN Game as a Learning Media for lab study can be used as a tool in the independent study process. Learning media already feasible for used as tools and practice preference so it can upgrade the interest on learning and can increase the result of the study in this lecture. 


\section{Conclusion}

ELIN game as a learning media for Industrial Electronic Study will be develop with using MDLC Modelling. MDLC Consist of 6 steps, which are Analysis all the component need stage, design stage, obtaining content material stage, assembly stage, testing stage and distribution stage. Based on the feasibility test by lecture expert and media expert, get the high validity coefficient value 1, so the Notation Block Game can be used as a learning media in the art study. Percentage feasibility of this game is $89 \%$ and categorized as "VERY SUITABLE" to use as a Learning Media in Lab Study Industrial Electronic.

\section{References}

[1] Al Fatta, Hanif. 2007. Analisis dan Perancangan Sistem Informasi. Yogyakarta: Andi Andang, Ismail. 2006. Education Games (Menjadi cerdas dan ceria dengan permainan edukatif). Yogyakarta: Pilar Media.

[2] Ariesto, Sutopo. 2003. Multimedia Interaktif dan Flash. Yogyakarta: PT. Graha IImu.

[3] Arsyad, Azhar. 2014. Media Pembelajaran. Jakarta: Rajagrafindo Persada. Binanto, Iwan. 2010.

[4] Multimedia Digital - Dasar Teori dan Pengembangannya. Yogyakarta: Andi.

[5] Burnette, Ed, 2010, Hello, Android: Intoducing Google's Mobile Development Platform 3rd Edition, The Pragmatic Bookshelf, Texas USA

[6] Clark, Donald. 2006. Games and e-learning. Caspian Learning.

[7] Indriana, Dina. 2011. Ragam Alat Bantu Media Pengajaran. Jogjakarta: Diva Pers.

[8] Lawshe, C.H. (1975). A quantitative approach to content validity. Personnel Psychology, 28, 563-575

[9] Lee, Wei-Meng. (2012). Beginning Android 4 Application Development. Idianapolis: John Wiley \& Sons, inc.

[10] McClarty, K. L. (2012). A Literature Review of Gaming in Education. Pearson: Eric Edu.

[11] Nasution, Arman Hakim. 2003. Metode Research: Penelitian Ilmiah. Jakarta: PT. Bumi Aksara.

[12] Roedavan, Rickman. 2016. Unity Tutorial Game Engine. Bandung: Informatika.

[13] Rusman. 2012. Model-Model Pembelajaran. Bandung: Seri manajemen Sekolah bermutu.

[14] Sadiman, Arif S. 2011. Media Pendidikan, Pengertian, Pengembangan, dan Pemanfaatannya. Jakarta: Raja Grafindo Persada. 
[15] Sudjana, Nana. 2011. Penilaian Hasil Proses Belajar Mengajar. Bandung: Remaja Rosydakarya.

[16] Sudyatmika, P.A. 2014. Pengembangan Aplikasi Augmented Reality Book Pengenalan Objek Wisata Taman Ujung Soekasada Dan Taman Ar Tirta Gangga Di Kabupaten Karangasem. Universitas Pendidikan Ganesha.

[17] Sukamto, R. A., dan Shalahudin, M. 2014. Rekayasa Perangkat Lunak Terstruktur Dan Berorientasi Objek. Bandung: Informatika Bandung.

[18] Thiagarajan, S., D. S. Semmel \& M. I. Semmel. 1974. Instructional Development for Training Teachers of Exceptional Children: A Sourcebook. Minneapolis: Indiana University.

[19] Ulrich, Karl T \& Steven. 2001. Perancangan \& Pengembangan Produk. Jakarta: Salemba Teknika.

[20] Walker, D.F. dan Hess, R.D. 1984. Instructional Software: Principles and Prespectives for Design and Use. Belmont: Wadsworth Publishing Company.

[21] Wolber, David., Abelson, Hal., et all., App Inventor: Create Your Own Android Apps, Canada: O'Reilly, 2011, hal 19.

[22] Yörük, N., I. Morgil \& N. Seçken. 2010. The Effects of Science, Technology, Society, Environment (STSE) Interactions on Teaching Chemistry. Natural Science, 12(2): 14171424. 